Ann. Biol. anim. Bioch. Biophys., 1978, 18 (1), 45-51.

\title{
Placental growth hormone in sheep : purification, properties and variations
}

par J. MARTAL

Laboratoire de Physiologie de la Lactation, I.N.R.A. 78350 Jouy-en-Josas, France.

Summary. The purification of a placental growth-promoting hormone, Ovine Chorionic Somatomammotropin (OCS), and its main physicochemical, immunological and biological properties were studied. OCS diffused into the amniotic fluid and was excreted into the allantoid fluid, but its concentrations in these compartments remained very low by comparison with the maternal or fetal serum. The total growth activity, as measured by radioreceptor assay in fetal serum, remained almost constant from day 60 to day 140 of pregnancy. Thus, fetal weight increase and total amounts of growth-promoting activities present (OCS + OGH) per fetus were about proportional.

\section{Introduction.}

The endocrine control of fetal growth is not yet completely understood since anencephalic or hypophysectomized fetus nevertheless grows normally or almost normally (Jost, 1951 ; Liggins and Kennedy, 1968). In sheep, serum concentrations of hypophyseal fetal growth hormone have been measured by radioimmunoassay (Bassett et al., 1970), but they do not correlate satisfactorily with fetal weight changes. A lactogenic hormone has been recently purified from sheep placenta (Handwerger et al., 1974 ; Martal and Djiane, 1975 ; Martal, Djiane and Delouis, 1975 ; Fellows et al., 1976 ; Chan, Robertson and Friesen, 1976); this hormone can bind to ovine growth hormone receptors from liver (Handwerger et al., 1974 ; Chan Robertson and Friesen, 1976 ; Martal and Djiane, 1976), and to allow the growth of hypophysectomized rats (Chan, Robertson and Friesen, 1976 ; Martal and Djiane, 1976). Its mammotropic (Djiane et al., 1975) and growth-promoting properties have justified its name : Ovine Chorionic Somatomammotropin (OCS) (Martal and Djiane, 1976).

The placental production of OCS has been analysed (Martal and Dijane, 1977) and the placental localization of its secretion determined (Dubois, Martal and Djiane, 1976 ; Marfal, Djiane and Dubois, 1977). A close correlation between felal growth and changes in total amounts of fetal growth hormones of placental and hypophyseal origin has not yet been demonstrated in any species; the present communication outlines our main results in this field. OCS levels in the amniotic and allantoid fluids have also been studied. 


\section{Material and methods.}

The radioimmunoassay for ovine growth hormone was performed according to the method already described (Martal, 1972, 1973) and the radioreceptor assay for growth and lactogenic activities as used by Shiu, Kelly and Friesen (1973).

The purification of OCS was performed according to our method with small modifications (Martal and Djiane, 1975). Placentae were obtained from Préalpes du Sud ewes after slaughter at various stages of pregnancy. They were immediately frozen at $-20^{\circ} \mathrm{C}$. Frozen fetal cotyledons were ground, thawed and homogenized in $0.01 \mathrm{M}$ phosphate buffer, $\mathrm{pH} 7.6$ with $0.3 \mathrm{M} \mathrm{KCl}$, filtered through cheese-cloth, stirred at $\mathrm{pH}$ 9.5 for $4 \mathrm{~h}$ and centrifuged $(12000 \mathrm{~g}, 30 \mathrm{~min}$.). The supernatant was allowed to precipitate overnight at $\mathrm{pH} 4.5$, then was centrifuged. The supernatant was precipitated at $\mathrm{pH} 6.9$ with ammonium sulfate ( $65 \mathrm{p} .100$ saturation), and the precipitate dissolved in $0.01 \mathrm{M}$ sodium borate buffer, $\mathrm{pH} 8$, then dialyzed against the same buffer. After DEAE Sephadex A 25 chromatography (Pharmacia, Uppsala, Sweden) in a column $(8 \times 20 \mathrm{~cm})$ equilibrated with the previous buffer, the effluent was dialyzed and lyophilized. A filtration on Ultrogel AcA 44(LKB) was performed in a column $(4.5 \times 140 \mathrm{~cm}$, $45 \mathrm{ml} / \mathrm{h}$ ) equilibrated with $0.025 \mathrm{M}$ ammonium bicarbonate buffer with $0.1 \mathrm{M} \mathrm{KCl}$. After lyophilization the active fractions were applied separately to a CM Sephadex C 25 (Pharmacia) column (0.01 M phosphate buffer, pH 5) (fig. 1).

Bioassay of growth activity: Wistar rats weighing about $100 \mathrm{~g}$ were hypophysectomized by the transauricular route. Only the rats which failed to gain more than a

$$
\text { CM - Sephadex C25 }(1.7 \times 14 \mathrm{~cm}) \text {. }
$$

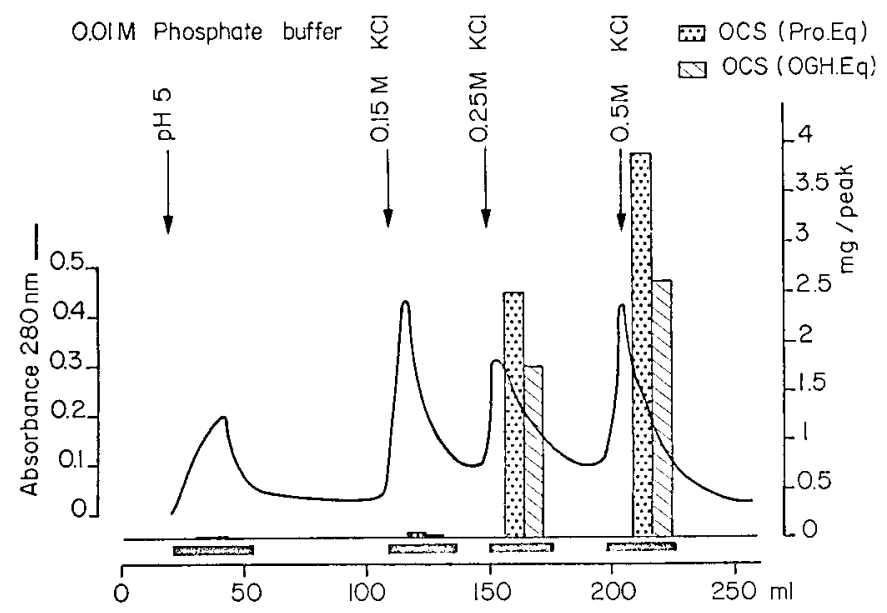

FIG. 1. - Chromatogram of the active Sephadex material on a column of carboxymethyl (CM) Sephadex $C 25$ equilibrated with $0.01 \mathrm{M}$ phosphate buffer, $\mathrm{pH} 5$, without $\mathrm{KCl}$. A stepwise gradient using $\mathrm{KCl}$ in the same buffer was run from $0.15 \mathrm{M}$ to $0.5 \mathrm{M} \mathrm{KCl}$. 
few grams in the 15 days following hypophysectomy were used. They were injected intraperitoneally $(0.5 \mathrm{ml})$ daily, with $100 \mu \mathrm{g}$ of BGH Pentex $(1 \mathrm{lU} / \mathrm{mg})$ or $300 \mu \mathrm{g}$ of OCS. Hypophysectomized control rats were injected with $300 \mu \mathrm{g}$ of OCS and an amount of horse immunoglobulins against BGH sufficient to neutralize about $200 \mu \mathrm{g}$ of $\mathrm{OGH}$. A second lot of hypophysectomized control rats was injected with a solution of $\mathrm{NaCl}(9$ p. 1000) ; a third control lot was composed of normal rats injected with $\mathrm{NaCl}(9$ p. 1000).

Gain in body weight was measured every other day during three weeks. At the end of this period, the animals were killed and the width of the tibial epiphyseal cartilages measured according to Papkoff and Li (1962).

\section{Results and discussion.}

1. Purification. OCS has been purified more than one thousandfold. Its activity as measured by bioassays and radioreceptor assays was found to be equivalent to about $15 \mathrm{IU} / \mathrm{mg}$ of NIH ovine prolactin standard $(24 \mathrm{IU} / \mathrm{mg})$ and about $0.3-0.5 \mathrm{IU} / \mathrm{mg}$ of $\mathrm{NIH}$ OGH 59 or BGH Pentex $(1 \mathrm{lU} / \mathrm{mg})$. Purified OCS preparations were not contamined either by prolactin or by growth hormone, according to immunological assays. The growth activity of OCS preparations is more labile than the lactogenic activity. Similarly ${ }^{125}$--labelled OCS lost growth activity faster than lactogenic activity.

2. Biophysical and biochemical properties (Martal and Djiane, 1975). The apparent molecular weight of OCS is about 20 000-22 000 daltons, as measured by SDS polya-

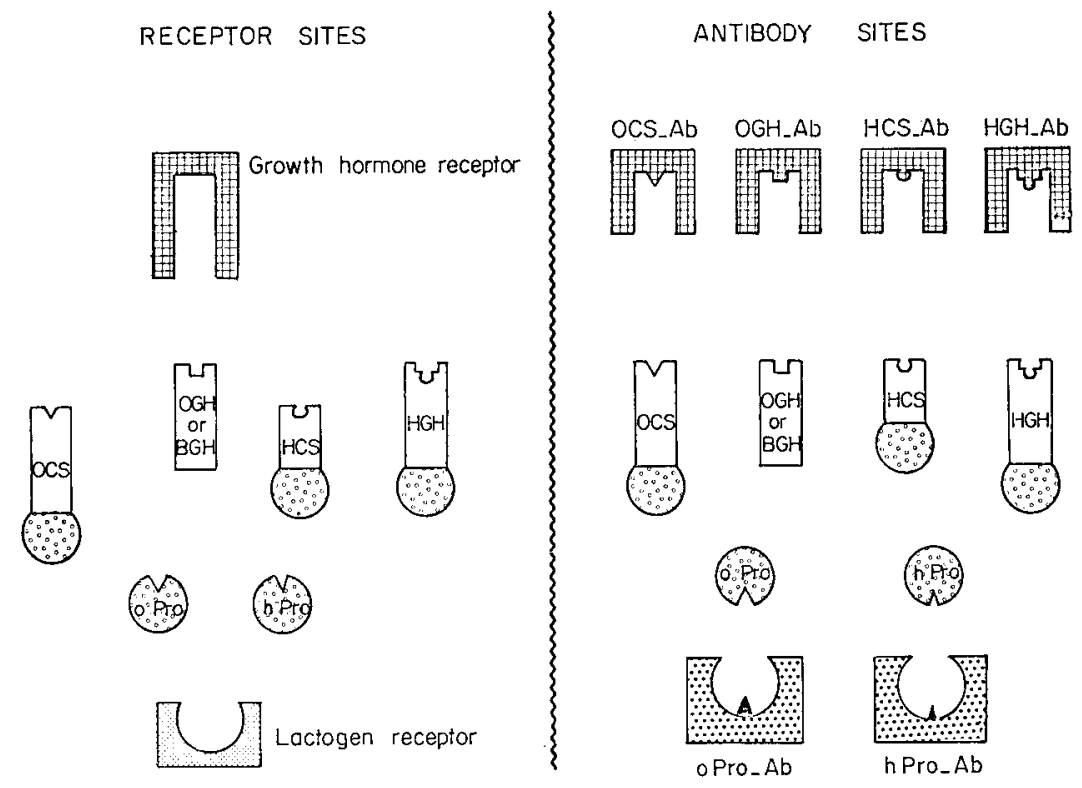

FIG. 2. - Comparison befween fonctional specificity of receptors and narrow species specificity of immunoglobulins. Ab : Antibodies against hormones ; OCS, HCS : Ovine, Human Chorionic somatomammotropin; OGH, BGH, HGH : Ovine, Bovine and Human growth hormone; o Pro, h Pro : ovine, human prolactin. 
crylamide gel electrophoresis and by gel filtration. It is close to those described for hypophyseal lactogenic and growth hormones. Electrophoretic mobility and $\mathrm{pl}$ of OCS are very close to $\mathrm{OGH}$ values and very different from ovine prolactin, HGH and HCS.

3. Immunological properties were determined by immuno-diffusion (Ouchterlony method) and by immunoprecipitation in tubes (Martal and Djiane, 1975), by radioimmunoassay (Martal, 1973) and by immunofluorescence (Dubois et al., 1976 ; Martal et al., 1977).

The main results are summarized in figure 2. No immunological cross-reaction was observed between OCS on one hand, and ovine and human prolactins, ovine, bovine and human growth hormones and human chorionic somatomammotropin on the other.

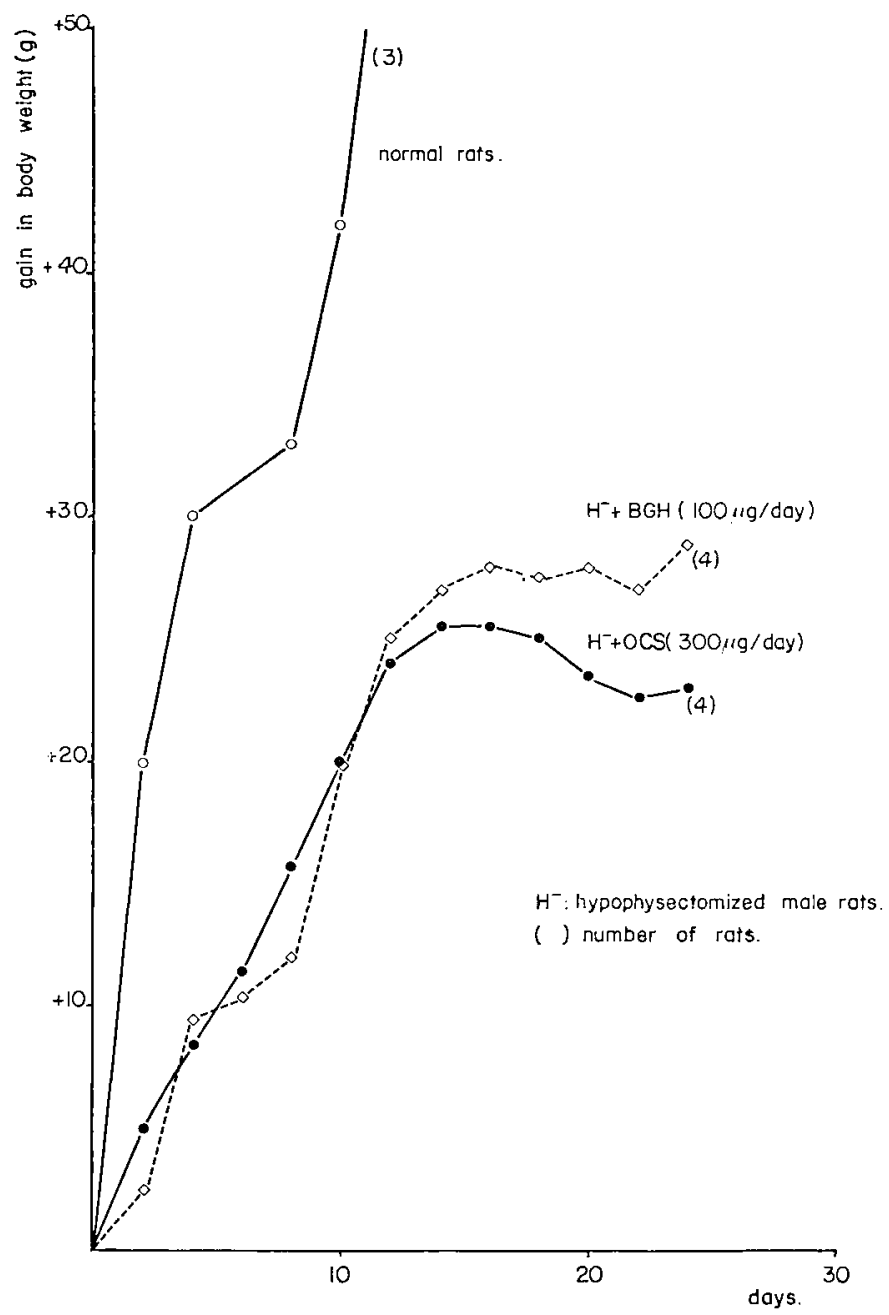

FIG. 3. - Gain in body weight of normal control rats and hypophysectomized rats injected (daily, intraperitoneally) with BGH $(100 \mu \mathrm{g})$, OCS $(300 \mu \mathrm{g})$. 


\section{Growth-promoting activity.}

a) Binding to growth hormone receptors. OCS binds specifically to growth hormone receptors in the liver; figure 2 schematizes the functional specificity of receptors as opposed to the narrow species specificity of the immunoglobulins.

b) Weight gain of hypophysectomized rats. Figure 3 shows the weight increase of hypophysectomized rats and its levelling off after 12 days of injection, presumably due to an anti-hormone effect. The gains obtained with $100 \mu \mathrm{g} \mathrm{BGH}$ and $300 \mu \mathrm{g} \mathrm{OCS}$ are equivalent, hence the OCS preparation is about three times less active than both the Pentex and N.I.H. standards. Hypophysectomized control rats do not gain weight, whereas normal rats grow much faster than the treated animals. Anti-BGH (or OGH) immunoglobulins do not present the growth-promoting effect of OCS, which confirms both the absence of $\mathrm{OGH}$ contamination and the lack of immunological cross-reaction beiween $O G H$ and OCS.

c) Increase of the width of epiphyseal cartilage. The results completely confirm the weight increase data (Martal and Djiane, 1976) ; hence OCS stimulates bone growth.

5. Variations of OCS levels in the serum (fig. 4).

a) In the ewe, radioreceptor assays for the growth-promoting activity of OCS have been performed by Martal and Djiane (1976) ; the OCS concentrations expressed either as $\mathrm{OGH}$ equivalents or prolactin equivalents increase during pregnancy (Kelly ef al., 1974 ; Djiane and Kann, 1975) until they reach a maximum level at about 120 days; at that time they amount to approximately three times the concentration in the fetal serum, after substracting fetal $O G H$ values; these values are considerably

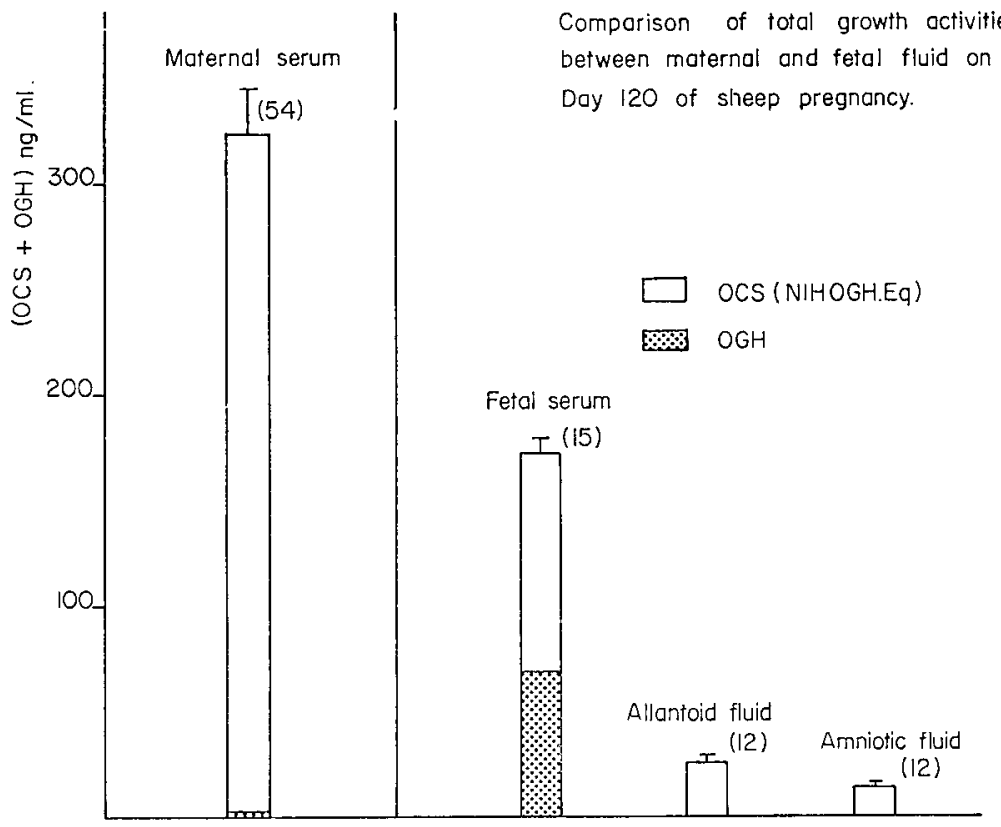

FIG. 4. 
higher than the hypophyseal growth hormone concentrations in the maternal serum, which remain very low during pregnancy (Bassett et al., 1970 ; Martal, 1973).

b) In the fetus, pituitary growth hormone $(O G H)$ increases in the course of pregnancy and reaches very high values at 120 days (fig. 4). As opposed to the ewe, the sum of growth-promoting activities (OCS $+\mathrm{OGH}, \mathrm{ng} / \mathrm{ml}$ ) remains almost constant throughout gestation (Martal, 1977, in press), resulting in a close proportionality between the fetal weight and the total amount of growth-promoting activities present (fig. 5).

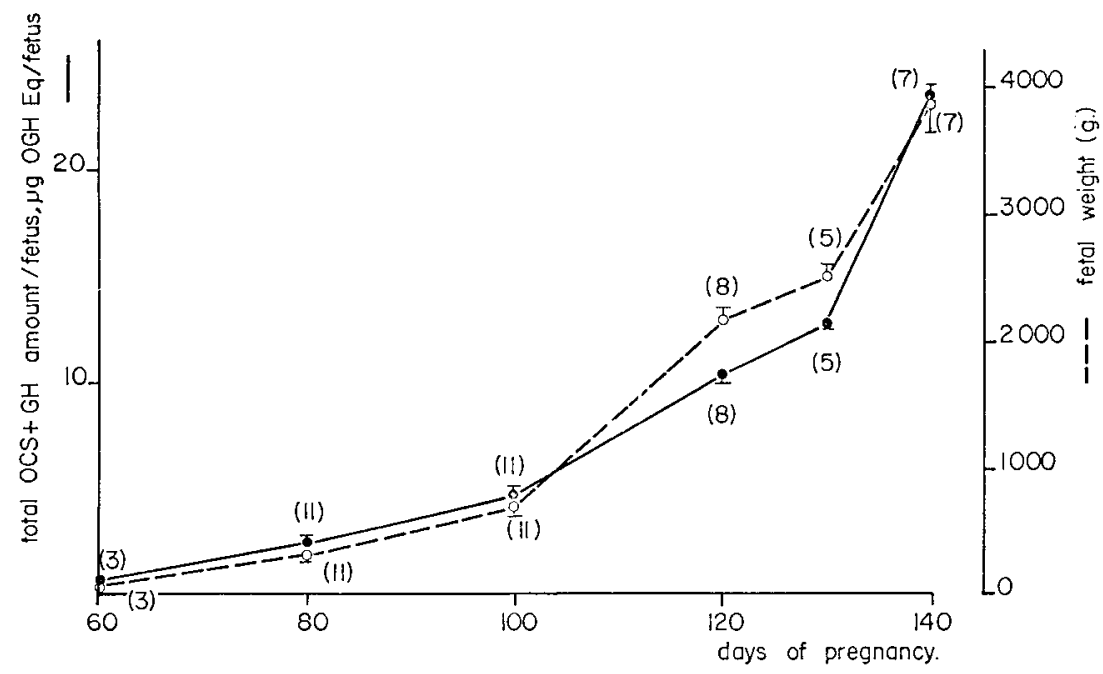

FIG. 5. - Proportionality between fetal weight and total amounts of growth hormones (OGH and OCS) per fefus during sheep pregnancy.

c) Concerning placental membranes. It may be interesting to mention that OCS seems to penetrate through the amniotic membrane in small amounts (fig. 4), OCS concentrations in the amniotic fluid remaining constant throughout pregnancy (Martal, 1977, in press). The ratio between growth hormone and lactogenic potencies of OCS appears to be similar in the amniotic fluid and fetal blood (approximately 1/2), whereas it drops to $1 / 4$ in the allantoid fluid on day 120 of pregnancy. This may suggest that the growth-promoting activity is destroyed by the kidneys to a larger extent than the lactogenic activity.

To summarize these data, it may be suggested that during the first half of gestation, fetal growth is essentially controlled by OCS, whereas during the second half of pregnancy, growth control is obtained through the combined action of OCS and fetal OGH. In the ewe, OCS may participate in the control of pregnancy anabolism which results in fetal growth and in promoting mammary development.

Réunion Groupe Développement INRA/Productions animales Montpellier, 17-18 mai 1977. 
Acknowledgments. - We are particularly grateful to Mrs Nicole Chêne for her expert technical assistance and Professor Hubert Clauser for numerous suggestions and for the translation of the manuscript. This work has been greatly facilitated thanks to financial grants from the CNRS, Paris, France (ATP $n^{\circ} 2152$ ) and from the DGRST, Paris, France (n० 757 1651).

Résumé. La purification d'une hormone de croissance placentaire (Ovine Chorionic Somatomammotropin, OCS) est décrite ainsi que les principales propriétés physico-chimiques, immunologiques et biologiques de croissance. L'OCS diffuse dans le liquide amniotique ef est excrétée dans le liquide allantoïdien, mais les concentrations restent très basses par rapport aux niveaux sériques de la mère ef du fotus. L'activité de croissance totale, mesurée par dosage radio-récepteur dans le sérum des fœłus d'agneaux esi quasiment constante du $60^{\mathrm{e}}$ au $140^{\mathrm{e}}$ jour de gestation. II en résulte une corrélation étroite entre la croissance pondérale du fœetus et la quantité totale d'activité de croissance (OCS + OGH) par fœetus.

\section{References}

BASSETT J. M., THORBURN G. D., WALLACE A. L. C., 1970. The plasma growth hormone concentration of the fotal lamb. J. Endocrin., 48, 251-263.

CHAN J. S. D., ROBERTSON H. A. FRIESEN H. G., 1976. The purification and characterization of ovine placental lactogen. Endocrinology, 98, 65-76.

DJIANE J., KANN G., 1975. Mise en évidence de l'activité lactogène et mesure dans le sérum de l'activité prolactinique du placenta chez la Brebis au cours de la gestation. C. R. Acad. Sci. Paris, Série D 280, 2785-2788.

DJIANE J., KANN G., DELOUIS C., MARTAL J., 1975. Placental lactogenic hormone : plasma levels in ruminants. Study of its role on mammogenesis and lactogenesis in the ewe. Proc. int. symp. on Growth hormone and related peptides, Milan, Suppl., 1, p. 128. Ric. Sci. Ed., Educazione Permanente, Milan.

DUBOIS M., MARTAL J., DJIANE J., 1976. Immunofluorescence localization of placental lactogen. Proc. 5th int. Congr. Endocr., Hamburg, p. 25, Brühlsche Univ. Drucherei, Giessen, W. Germany.

FELLOWS R. E., BOLANDER F. F., HURLEY T. W., HANDWERGER S., 1976. Isolation and characterization of bovine and ovine placental lactogen, 315-326. In PECILE A., MULLER E. E. Growth hormone and related peptides. Excerpta Med. Found., Amsterdam.

HANDWERGER S., MAURER W., BARRETT J., HUREY T., FELLOWS R. E., 1974. Evidence for homology between ovine and human placental lactogens. Endocr. Res. Comm., 1, 403-413.

JOST A., 1951. La physiologie de l'hypophyse foetale. Biol. méd., 40, 205-229.

KELLY P. A., ROBERTSON H. A., FRIESEN H., 1974. Temporal patterns of placental lactogen and progesterone secretion in sheep. Nature, Lond., 248, 435-437.

LIGGINS G. C., KENNEDY P. C., 1968. Effects of electrocoagulation of the fotal lamb hypophysis on growth and development. J. Endocrin., 40, 371-381.

MARTAL J., 1972. Détermination radioimmunologique des hormones de croissance ovine ef bovine : étude des conditions d'iodation et obtention d'une hormone somatotrope radioiodée sans prolactine contaminante. C. $R$. Acad. Sci., Paris, Série D, 274, 2893-2896.

MARTAL J., 1973. Dosage radioimmunologique des hormones de croissance ovine et bovine : technique et applications. C. R. Acad. Sci., Paris, Série D, 277, 221-224.

MARTAL J., DJIANE J., 1975. Purification of a lactogenic hormone in sheep placenta. Biochem. biophys. Res. Commun., 65, 770-778.

MARTAL J., DJIANE J., DELOUIS C., 1975. Isolation and characterization of an ovine placental lactogenic hormone. Proc. int. Symp. on Growth hormone and related peptides, Milan, Suppl. 1 , p. 125. Ric. Sci. Ed., Educazione Permanente, Milan.

MARTAL J., DJIANE J., 1976. Mammotrophic and growth promoting activities of a placental hormone in sheep. Proc. Satellite Symp. - $5^{\text {th }}$ Int. Congr. Endocr. Hormonal control in Fetal Development, Paris. In J. Steroid Biochem., 1977, 8, 415-417. 
MARTAL J., DJIANE J., 1977. The production of chorionic somatomammotrophin in sheep. J. Reprod. Fert., 49, 285-289.

MARTAL J., DJIANE J., DUBOIS M., 1977. Localization by immunofluorescence of ovine placental lactogen (Submitted for publication).

PAPKOFF H., LI C. H., 1962. Hypophyseal Growth Hormone. R. I. DORFMAN, Methods in hormone research, 2, 671-704. Acad. Press. N. Y. and London.

SHIU R. P. C., KELLY P. A., FRIESEN H. G., 1973. Radioreceptor assay for prolactin and other lactogenic hormones. Science, N. Y., 180, 968-970. 